\title{
Criminalising Medical Malpractice
}

The criminalisation of healthcare malpractice has become a highly topical and somewhat controversial question in recent years. Studies have demonstrated that in England and Wales, the trend towards holding healthcare professionals to account for malpractice is rapidly growing, abolishing the deference doctors enjoyed decades ago. The changing attitude of judges to claims for clinical negligence has been well documented. The role of the criminal process in England and Wales has been less fully analysed with the criminal law playing a very limited role until recently in the regulation of poor healthcare practice. In contrast, in France, the criminal process has for a long time been invoked more readily to respond to cases of healthcare malpractice, which involved even mere errors.

This book compares English and French criminal law responses to healthcare malpractice and considers what lessons the French model can provide for potential reform in England and elsewhere. The book takes the HIV-contaminated blood episode as a primary example of the different approaches France and England have in dealing with healthcare malpractice. Kazarian emphasises the impact of rules of substantive criminal law and criminal procedure on the way in which healthcare malpractice is criminalised in a given country.

This book explores the key lessons to be drawn on whether the criminal process is an appropriate means to respond to instances of healthcare malpractice. It proposes that features of French criminal law and criminal procedure might be useful to counteract healthcare malpractice.

Mélinée Kazarian is a lecturer in law at the University of Southampton. Mélinée's research interests are in medico-legal, criminal and comparative law issues, in particular the question of the criminalisation of negligence in the common law and civil law traditions. She has published widely on recent medico-legal debates, focusing on a comparative analysis of French and English criminal responses to healthcare scandals. She has been involved in different research projects which aimed to offer a comprehensive analysis of the role of the criminal justice system in regulating healthcare practice and ethics in the UK. 
$\Longrightarrow$ Taylor \& Francis Taylor \& Francis Group http://taylorandfrancis.com 


\title{
Criminalising Medical Malpractice A Comparative Perspective
}

\section{Mélinée Kazarian}


First published 2021

by Routledge

2 Park Square, Milton Park, Abingdon, Oxon OX14 4RN

and by Routledge

52 Vanderbilt Avenue, New York, NY 10017

Routledge is an imprint of the Taylor of Francis Group, an informa business

(C) 2021 Mélinée Kazarian

The right of Mélinée Kazarian to be identified as author of this work has been asserted by her in accordance with sections 77 and 78 of the Copyright, Designs and Patents Act 1988.

All rights reserved. No part of this book may be reprinted or reproduced or utilised in any form or by any electronic, mechanical, or other means, now known or hereafter invented, including photocopying and recording, or in any information storage or retrieval system, without permission in writing from the publishers.

Trademark notice: Product or corporate names may be trademarks or registered trademarks, and are used only for identification and explanation without intent to infringe.

British Library Cataloguing-in-Publication Data

A catalogue record for this book is available from the British Library

Library of Congress Cataloging-in-Publication Data

Names: Kazarian, Mélinée, author.

Title: Criminalising medical malpractice : a comparative perspective / Mélinée Kazarian.

Description: Abingdon, Oxon ; New York, NY : Routledge, 2020. | Based on author's thesis (doctoral - University of Manchester, 2013 ) issued under title: The role of the criminal law and the criminal process in healthcare malpractice in France and England. | Includes bibliographical references and index.

Identifiers: LCCN 2020005583 (print) | LCCN 2020005584 (ebook) | ISBN 9781138297562 (hardback) | ISBN 9781315099170 (ebook)

Subjects: LCSH: Medical personnel-Malpractice-EnglandCriminal provisions. | Medical personnel-Malpractice-FranceCriminal provisions.

Classification: LCC KJC8410 .M39 2020 (print) | LCC KJC8410 (ebook) | DDC 345.41/025—dc23

LC record available at https://lccn.loc.gov/2020005583

LC ebook record available at https://lccn.loc.gov/2020005584

ISBN: 978-1-138-29756-2 (hbk)

ISBN: 978-1-315-09917-0 (ebk)

DOI: $10.4324 / 9781315099170$ 
To my son 
$\Longrightarrow$ Taylor \& Francis Taylor \& Francis Group http://taylorandfrancis.com 


\section{Cotents}

Acknowledgements $\quad-x$

1 Introduction 1

'Responsable mais pas coupable' 1

The over-criminalisation of healthcare malpractice? 3

Aims and methodology 6

Assessing the role of criminalisation in healthcare practice 10

The criminal process and healthcare in England and Wales 12

Criminalising healthcare malpractice in France: a product of

legal tradition 14

Rethinking criminal liability for healthcare malpractice 18

The structure of this book 21

2 Healthcare negligence in French and English criminal law

Introduction 24

Data on criminal prosecutions involving healthcare

professionals 25

A wider use of the criminal law in France 26

When is negligence a crime in France and England and

Wales? 28

Individual criminal offences 31

Homicide 33

Non-fatal offences against the person 39

Corporate criminal offences 42

$A$ victim-oriented approach to causation? 46

Conclusion 49 
viii Contents

3 Criminal proceedings for healthcare negligence in France and England and Wales

Introduction 51

The role of victims 52

Constitution de partie civile 52

Advantages for victims of medical negligence 55

The role of prosecutors 58

The role of investigators 61

The trial phase: the role of judges and juries 66

Conclusion 68

4 Contaminated blood: a tale of two scandals

Introduction 70

Background 71

Victims of the tainted blood scandal in England and Wales 74

The 'Langstaff Inquiry' 75

Systemic failings or culpable omissions? 76

The blood supply organisation 76

Knowledge on HIV and hepatitis $C 78$

Self-sufficiency 81

Public health measures 82

a) Donor screening and HIV-testing 83

b) Heat treatment (and supply) of contaminated blood stocks 86

Information to patients 88

Blood collected from French prisons 90

Possible criminal charges 91

Fatal and non-fatal offences against the person 91

a) GNM 92

b) Inflicting $G B H 93$

Health and safety offences 94

Corporate manslaughter 94

Product liability offences 95

Insufficient compensation 97

Conclusion 100

5 Is criminal law the answer to individual healthcare

negligence?

Introduction 102

No accountability for error/'simple' negligence 104

Errors cannot be deterred 104

Understanding errors in the broader systemic context 107 
Accountability for reckless and/or deliberate behaviour abandoning the gross negligence test? 109

Conduct offences 111

Including individual decision-makers in the scope of criminal liability 114

Improving our prosecutorial policy? 116

Conclusion 117

6 Institutions in the dock and alternatives to the criminal process

Introduction 119

Systemic failings and criminal liability 120

The corporate 'person' in the healthcare context 122

Establishing the culpability of a health institution 123

Using corporate offences in the healthcare context 125

Liability under the CMCHA 2007126

Liability under the HSWA 1974128

Liability under the CJCA 2015130

The effect of criminal sanctions on health institutions 130

Deterrence 131

Incapacitation and rehabilitation 132

Retribution and demands of victims 134

Prevention and transparency 135

Alternatives to the criminal process 136

Regulatory mechanisms 136

Support and reparation 141

Conclusion 143

7 Conclusion

Explaining differences 145

Lessons from France 146

Improving responses to healthcare failings 148

Bibliography

Index 


\section{Acknowledgements}

I would like to thank my former supervisor and colleague Professor Margot Brazier for her continued support and for her insightful comments on earlier drafts of this book.

I would also like to extend my gratitude to my former supervisor and colleague Anne-Maree Farrell for her encouragement, and Professor Amel Alghrani for always believing in me.

Draft chapters of this book were also greatly improved thanks to the help, comments and feedback from Dr Alexandra Mullock, Dr Claire Lougarre, Dr Oche Onazi, Professor Hazel Biggs, Professor David Gurnham, Dr Harry Annison, Dr Jacob Eisler and Dr Alun Gibbs.

I am grateful to my colleagues at the University of Southampton, Dr Haris Psarras, Professor Adrien Viens, Dr Natasha Hammond-Browning, and members of HEAL and CLPS for their support and encouragement throughout this process.

Finally, I thank my caring and loving parents, partner, family and friends for their ongoing support with this project. 


\section{Introduction}

\section{'Responsable mais pas coupable'}

Those were the words pronounced by Georgina Dufoix (then French Social Affairs Minister) on 4 November 1991, on a French national TV channel, when she was asked to explain her role in the 1980s contaminated blood scandal. ' $I$ feel deeply responsible', said Dufoix, 'however, I do not feel guilty, because really, at the time, we made decisions in a certain context, which were decisions that seemed right to us'. ${ }^{2}$ The contaminated blood scandal had resulted in thousands of victims being infected with HIV and hepatitis $\mathrm{C}$ following the failure of health authorities to prevent the provision of tainted blood products to patients. In France, three sets of criminal proceedings saw prescribing doctors, blood centre officials and three ministers, including Dufoix, being prosecuted for various criminal offences such as deception and involuntary homicide. Dufoix, along with Laurent Fabius, then Prime Minister, was acquitted of the charges of involuntary homicide in $1999 .{ }^{3}$ Out of over 30 health officials who were prosecuted for the failure to prevent the provision of contaminated blood products to patients, only two blood centre officials were jailed for deception.

Although a similar episode of the same scale occurred in the United Kingdom (UK), criminal charges were not brought. Nearly 40 years after the start of the contamination, in June 2017, a full public inquiry, the 'Infected Blood Inquiry', was ordered by the then UK Prime Minister Theresa May, to shed light on the failings which led to thousands of people being infected with HIV and the hepatitis $\mathrm{C}$ virus. ${ }^{4}$ Following the contamination, victims were awarded ex gratia

1 In this book the 'contaminated blood scandal' is also referred to as the 'tainted blood scandal' or the 'infected blood scandal'.

2 J-A Heraud, F Kerr, T Burger-Helmchen, Management créatif des systèmes complexes (London: ISTE Editions 2019), 109.

3 E Favereau, 'Le procès du sang contaminé. Les trois accusés et l'avenir. Georgina Dufoix non coupable. Son action a été jugée positive', Libération (10 March 1999).

4 P Walker, A Topping, 'Theresa May Orders Contaminated Blood Scandal Inquiry', The Guardian (11 July 2017). 


\section{Introduction}

payments from various trusts and funds, ${ }^{5}$ but the UK Government always denied liability. ${ }^{6}$

A crucial question in this book is to find out whether health authorities in both countries were merely responsible for the contamination, or whether they were culpable of causing the contamination and the death of thousands of patients. In this book, I do not address obviously blameworthy wrongdoing which intentionally aims to hurt others. ${ }^{7}$ Instead, I discuss healthcare 'malpractice's in the context of failure to provide the level of safe care expected from healthcare services and individual professionals. The causes of healthcare failure are diverse and may include mistakes that reasonable and competent professionals make in the course of their practice. Sometimes failure may be the result of behaviour that reveals a more culpable frame of mind, where an individual might disregard the life, and health and safety, of others. Negligent behaviour in everyday life can have serious consequences depending on the type of activity involved. Negligence in the healthcare context more particularly may lead to tragic consequences including life-threatening injury or death. Paradoxically, an activity which aims to heal may instead harm or kill. Victims or their families consequently ask for reparation and justice, and sometimes seek to attribute blame to an individual or an institution. This may result in recourse to legal proceedings. ${ }^{9}$ Such legal proceedings may

5 Rt Hon Lord Archer, Independent Public Inquiry Report on NHS-Supplied Contaminated Blood and Blood Products, February 2009 (Archer Report), 73; Infected Blood Inquiry, Terms of Reference. www.infectedbloodinquiry.org.uk/sites/default/files/Terms-of-Reference-Infected-Blood-Inquiry.pdf; Additional payments to infected blood victims were made in 2017 in Scotland, Wales, Northern Ireland and England through infected blood support schemes: Scotland: https://nhsnss.org/services/practitioner/medical/scottishinfected-blood-support-scheme/;Wales:https://wibss.wales.nhs.uk/;NorthernIreland:www. hscbusiness.hscni.net/services/2876.htm; England: https://www.nhsbsa.nhs.uk/englandinfected-blood-support-scheme.

6 UK Government, Government Response to Lord Archer's Independent Inquiry Report on NHSsupplied Contaminated Blood and Blood Products, 20 May 2009, 1-2.

7 In this book, I am concerned with healthcare malpractice in the sense of error and disregard for the life of others, but not intentional wrongdoing as was the case in the Shipman scandal in England, where Doctor Shipman was sentenced to life imprisonment for the murder of numerous patients; see http://webarchive.nationalarchives.gov.uk/20090808154959/ www.the-shipman-inquiry.org.uk/backgroundinfo.asp, accessed 28 January 2020; 'Shipman Jailed for 15 Murders', BBC News (31 January 2000). Other examples of 'intentional' medical wrongdoing include the case of Dr Paterson, who was charged with 17 counts of wounding with intent, for performing unnecessary breast surgery on patients, or the case of Dr Bramhall, who was convicted of assault for branding his initials on patients' livers. See G James Rev'd (Chair), Report of the Independent Inquiry into the Issues raised by Paterson, February 2020; A Topping, 'Breast Surgeon Ian Paterson Jailed for 15 Years for Carrying Out Needless Operations', The Guardian (31 May 2017); “ "Liver Branding” Surgeon Simon Bramhall Fined $£ 10,000$ ', BBC News (12 January 2018).

8 The terms 'medical malpractice' and 'healthcare malpractice' will be used interchangeably throughout this book as general terms for errors, negligence, and reckless or indifferent conduct endangering the life and health of patients which occur in the healthcare setting.

9 A Merry, W Brookbanks, Merry and McCall Smith's Errors, Medicine and the Law (2nd edn, Cambridge: Cambridge University Press 2017), 1. 
take several forms. They may involve disciplinary proceedings against responsible professionals, claims for compensation for the harm caused, or criminal proceedings. This book focuses on the use of criminal proceedings in the healthcare malpractice context. It explores some of the key factors in the criminal justice system that contribute to explaining the differences between the approaches taken by France and by England and Wales on this matter, and considers whether lessons could be learnt from the French experience on the use of the criminal law in healthcare malpractice cases.

\section{The over-criminalisation of healthcare malpractice?}

In the past decade in England and Wales, ${ }^{10}$ the medical profession has expressed growing concern that health professionals may unjustly face criminal prosecutions for gross negligence manslaughter (GNM) as a result of errors or negligence which caused the death of patients. ${ }^{11}$ Instances of health professionals being prosecuted for and/or convicted of GNM are perceived to have risen in recent years, and have included health professionals who were characterised by their peers as both diligent and competent professionals. ${ }^{12}$ Several other examples have included health professionals committing negligence in pressured and understaffed healthcare institutions. In November 2015, Dr Bawa-Garba and Nurse Amaro were both convicted of GNM for causing the death of Jack Adcock, a 6-year-old boy with Down syndrome, and were subsequently struck off the medical and nursing registers by the General Medical Council (GMC) and

10 This book compares the law in France and in England and Wales in relation to negligence committed within the healthcare setting. The law in other countries of the United Kingdom is not thoroughly discussed but may be mentioned where relevant.

11 Examples of 'medical manslaughter' convictions include the convictions of Dr Adomako, Drs Misra and Srivastava, Dr Garg, and more recently Dr Sellu and Dr Bawa-Garba. Dr Sellu was convicted and jailed for GNM, but his conviction was then quashed by appeal judges in 2016 as his conduct did not reach the criminal standard: C Dyer, 'Senior Surgeon's Conviction for Manslaughter Is Quashed', (2016) British Medical Journal 355; 'David Sellu Trial: Doctor's Conviction Over Patient's Death Quashed', BBC News (15 November 2016); see also $R v$ Adomako [1994] 3 WLR 288; $R$ v Misra; $R$ v Srivastava [2004] EWCA Crim 2375; $R v$ Garg (Sudhanshu) [2012] EWCA Crim 2520; $R v$ Bawa-Garba [2016] EWCA Crim 1841; P Gooderham, B Toft, 'Involuntary Automacity: A Potential Legal Defence to an Allegation of Clinical Negligence?' (2009) 18(1) Quality and Safety in Health Care 69; M Brazier, A Alghrani, 'Fatal Medical Malpractice and Criminal Liability', (2009) 25(2) Journal of Professional Negligence 51.

12 C Dyer, 'Sellu Is Cleared of Medical Misconduct', (2018) British Medical Journal 360; S Boseley, 'Doctors Sign Letter Expressing Worry Over Criminalisation of Surgeon', The Guardian (6 August 2015). The use of the offence of GNM in the healthcare context has not been restricted to doctors: In July 2016, an optometrist, Mrs Honey Rose, was convicted of GNM, but the decision to convict her was quashed as the Court of Appeal decided that she could not have reasonably foreseen an obvious and serious risk of death. $R v$ Honey Maria Rose [2017] EWCA Crim 1168; see also 'Vincent Barker Death: Optometrist Honey Rose Conviction Quashed', BBC News (31 July 2017). As will be explained in Chapter 2, the law on GNM was somewhat clarified in this case. 


\section{References}

'Acquired Immunodeficiency in Haemophilia', (1983) 321(8327) The Lancet 745

'Acquired Immunodeficiency Syndrome', (1983) 321(8317) The Lancet 162

'Blood Transfusion, Haemophilia and AIDS', (1984) 324(8417-8418), The Lancet 1433

'Surveillance of the Acquired Immune Deficiency Syndrome in the United Kingdom, January 1982-July 1983', (1983) 287(6389) British Medical Journal 407

Allen N, 'Medical or Managerial Manslaughter', in Erin C, Ost S (eds), The Criminal Justice System and Health Care (Oxford: Oxford University Press 2007)

_ , 'Psychiatric Care and Criminal Prosecution', in Griffiths D, Sanders A (eds), Medicine, Crime and Society (Cambridge: Cambridge University Press 2013)

Ashworth A, 'Is the Criminal Law a Lost Cause?' (2000) 116 Law Quarterly Review 14

Ashworth A, Horder J, Principles of Criminal Law (7th edn, Oxford: Oxford University Press 2013)

Ausness RC, 'Retribution and Deterrence: The Role of Punitive Damages in Products Liability Litigation', (1985) 74(1) Kentucky Law Journal 40

Ayres I, Braithwaite J, Responsive Regulation: Transcending the Deregulation Debate (Oxford: Oxford University Press 1992)

Beaud O, Le sang contaminé (Paris: Presses Universitaires de France 1999)

Beaussier AL, Demeritt D, Griffiths A, Rothstein H, 'Accounting for Failure: Riskbased Regulation and the Problem of Ensuring Healthcare Quality in the NHS', (2016) 18(3-4) Health, Risk \& Society 206

Beckfield J, Olafsdottir S, Sosnaud B, 'Healthcare Systems in Comparative Perspective: Classification, Convergence, Institutions, Inequalities and Five Missed Turns', (2013) 29 Annual Review of Sociology 127

Bell J, French Legal Cultures (Cambridge: Cambridge University Press 2008)

Bernard-Requin M, 'SIDA et transfusion sanguine ou l'affaire du sang contaminé. Les difficiles qualifications pénales', (1998) 28(1) Médecine et Maladies Infectieuses 20

Bernstein S, Les cultures politiques en France (Paris: Seuil 1999)

Bertella Geffroy M-O, 'L'évolution des rapport justice-santé', (2004) 4(5) Les Tribunes de la santé 21

—-, 'Justice Pénale, Santé Individuelle et Santé Publique', (2008) (2) Droit de la Santé, Nos 282 à 283

Berridge V, AIDS in the UK: The Making of Policy. 1981-1994 (Oxford: Oxford University Press 1996)

Bettati C, Responsables et coupables, Une affaire de sang (Paris: Seuil 1993)

Beziz-Ayache A, Dictionnaire de Droit pénal général et procédure pénale (6th edn, Paris: Ellipses 2016)

Bibby J, Tomkins C, 'Would Criminalising Healthcare Professionals for Wilful Neglect Improve Patient Care?' (2014) 348 British Medical Journal 1

Black J, 'What Is Regulatory Innovation?' in Black J, Lodge M, Thatcher M (eds), Regulatory Innovation (Cheltenham: Edward Elgar 2005)

Blair P, Germain M, 'Corporate Criminal Intention in the Enforcement of Environmental Law', (2012) 24(1) Environment Law and Management 20

Bloom AL, Forbes CD, Rizza CR, 'HTLV-III, Haemophilia and Blood Transfusion', (1985) 290(6485) British Medical Journal 1901

Bouloc B, Procédure Pénale (27e edn, Paris: Dalloz 2019) 
Bouloc B, Matsopoulou H, Droit pénal général et procédure pénale (2le edn, Paris: Sirey 2018)

Bradley CM, 'Overview', in Bradley CM, Calamaras JL (eds), Criminal Procedure, A Worldwide Study (2nd edn, Durham, NC: Carolina Academic Press 2007)

Brazier M, Alghrani A, 'Fatal Medical Malpractice and Criminal Liability', (2009) 25(2) Journal of Professional Negligence 51

Brazier M, Allen N, 'Criminalizing Medical Malpractice', in Erin C, Ost S (eds), The Criminal Justice System and Health Care (Oxford: Oxford University Press 2007)

Brazier M, Cave E, Medicine, Patients and the Law (6th edn, Manchester: Manchester University Press 2016)

Brazier M et al., 'Improving Healthcare Through the Use of 'Medical Manslaughter'? Facts, Fears and the Future', (2016) 22(5-6) Clinical Risk 88

Brearey-Horne P, 'The Corporate Manslaughter and Corporate Homicide Act 2007 and Maternal Death: An Opportunity to Address Systemic Deficiencies in Maternity Services?' in Griffiths D, Sanders A (eds), Medicine, Crime and Society (Cambridge: Cambridge University Press 2013)

Brownsword R, Rights, Regulation and the Technological Revolution (Oxford: Oxford University Press 2008)

Burgelin JF, 'La médecine saisie par le principe de précaution', (2000) 184(5) Bulletin de l'Académie Nationale de Médecine 873

Carrère N, 'Le juge pénal et les professionnels de santé', (2008) 283 Gazette du Palais 23

Cartron D, 'Quelle place pour la victime d'un accident médical devant le juge pénal?' (2013) 5(27) Responsabilité civile et assurance 1

Cash J, 'The Blood Transfusion Service and the National Health Service', (1987) 295(6599) British Medical Journal 617

Casteret AM, L'affaire du sang (Paris: La Découverte 1992)

Chalmers J, Leverick F, 'Tracking the Creation of Criminal Offences', (2013) 7 Criminal Law Review 543

Chambaud L, 'How Healthy Is the French Health System?' The Conversation, 21 September 2017

Chamberlain JM, 'Risk-based Regulation and Reforms to Fitness to Practice Tribunals in the United Kingdom: Serving the Public Interest?' (2016) 18(5-6) Health, Risk \& Society 323

Childs M, 'Medical Manslaughter and Corporate Liability', (1999) 19(3) Legal studies 316

Clarkson CMV, 'Kicking Corporate Bodies and Damning Their Souls', (1996) 59(4) The Modern Law Review 557

— ' 'General Endangerment Offences: The Way Forward?' (2005) 32 University of Western Australian Law Review 131

Clarkson CMV, Keating HM, Cunningham SR, Criminal Law (7th edn, London: Thompson Sweet and Maxwell 2010)

Coffee JC, 'No Soul to Damn: No Body to Kick': An Unscandalized Inquiry into the Problem of Corporate Punishment', (1981) 79(3) Michigan Law Review 386

Commaret VD, La Loi Fauchon, 5 ans après (2006) Chron. N7, spec. N18 Droit Pénal

Cotte B, Guihal D, La Loi Fauchon, 5 ans de mise en oeuvre jurisprudentielle (2006) chron. N6, et spéc. N44 Droit Pénal

Cusson M, La criminologie (7e edn, Paris: Hachette 2017) 
Dannemann G, 'Chapter 11: Comparative Law: Study of Similarities of Differences?' in Reimann M, Zimmermann R (eds), The Oxford Handbook of Comparative Law (Oxford: Oxford University Press 2006)

Daury-Fauveau M, La responsabilité pénale du médecin (Bordeaux: Les études hospitalières 2003)

Davis KC et al., 'Acquired Immunodeficiency Syndrome in a Patient with Hemophilia', (1983) 98(3) Annals of Internal Medicine 284

De Cruz P, Comparative Law in a Changing World (3rd edn, New York, NY: Routledge-Cavendish 2007)

Dervieux V, 'The French System', in Delmas-Marty M, Spencer JR (eds), European Criminal Procedures (Cambridge: Cambridge University Press 2002)

Devaney S, Holm S, 'The Transmutation of Deference in Medicine: An Ethico-Legal Perspective', (2018) 26(2) Medical Law Review 202

Draycott T et al., 'The Role of Insurers in Maternity Safety. Best Practice and Research', (2015) 29(8) Clinical Obstetrics and Gynaecology 1126

Duff A, Answering for Crime: Responsibility and Liability in the Criminal Law (Oxford: Hart Publishing 2009)

Dyer C, 'Bristol Inquiry Condemns Hospital's Club Culture', (2001) 323(7306) British Medical Journal 181

—, 'Half of Doctors Investigated Over Mid Staffs Have Faced No Action, Says GMC', (2013) 346 British Medical Journal 872

— Journal 14

— , 'Senior Surgeon's Conviction for Manslaughter Is Quashed', (2016) British Medical Journal 355

— - 'Sellu Is Cleared of Medical Misconduct', (2018) British Medical Journal 360

- 'Society, Anger, Bewilderment: The Fallout from the Bawa-Garba Case', (2018) British Medical Journal 360

Elliott C, French Criminal Law (Cullompton: Willan 2001)

Engineer R, 'Punishing Corporate Negligence, Industrial Disasters and Criminal Law', (1989) 24(14) Economic and Political Weekly 711

Erin C, Ost S (eds), The Criminal Justice System and Heath Care (Oxford: Oxford University Press 2007)

Farrell AM, 'Contaminated Blood, a Comparative Study of Policy-Making Arising Out of HIV Contamination of the Blood Supply in France, the United Kingdom and Ireland' (PhD thesis, University of Manchester 2004)

, The Politics of Blood (Cambridge: Cambridge University Press 2012)

Farrell AM, Devaney S, 'Making Amends or Making Things Worse?' (2007) 27(4) Legal Studies 630

Farrell AM, Kazarian M, 'The Role of the Criminal Law in Healthcare Malpractice in France: Examining the HIV Blood Contamination Episode', in Griffiths D, Sanders A (eds), Medicine, Crime and Society (Cambridge: Cambridge University Press 2013)

Feinberg J, 'The Expressive Function of Punishment', in Feinberg J (ed), Doing and Deserving (Princeton: Princeton University Press 1970)

- Harm to Others (Oxford: Oxford University Press 1984)

Ferner RE, 'Medication Errors That Have Led to Manslaughter Charges', (2000) $321(7270)$ British Medical Journal 1212 
Ferner RE, McDowell SE, 'Doctors Charged with Manslaughter in the Course of Medical Practice, 1795-2005: A Literature Review', (2006) 99 Journal of the Royal Society of Medicine 309

Field S, 'Ten Years On: The Corporate Manslaughter and Corporate Homicide Act 2007: Plus ca Change?' (2018) International Company and Commercial Law Review 512

Gand P, 'Les pôles de santé publique, une organisation adaptée aux contentieux en matière de securité sanitaire', (2013) RDSS 813

— els"', (2014) 198(4-5) Bulletin de l'Académie Nationale de Médecine 715

Garfield S, The End of Innocence: Britain in the Time of AIDS (London: Faber and Faber 1995)

Gobert J, 'Corporate Criminality: Four Model of Fault', (1994) 14(3) Legal Studies 393

Gooderham P, 'No-one Fully Responsible': A 'Collusion of Anonymity' Protecting Health Care Bodies from Manslaughter Charges?’ (2011) Clinical Ethics 68

Gooderham P, Toft B, 'Involuntary Automaticity: A Potential Legal Defence to an Allegation of Clinical Negligence?' (2009) 18(1) Quality and Safety in Health Care 69

_- 'Involuntary Automaticity and Medical Manslaughter', in Griffiths D, Sanders A (eds), Medicine, Crime and Society (Cambridge: Cambridge University Press 2013)

Greilsamer L, Le procès du sang contaminé (Paris: Le Monde Editions 1992)

Gremy F, 'Contaminated Blood: The State's Renunciation and Incompetence in the Public Health Domain, a Long Tradition', (2002) 2(14) Santé Publique 179

Griffiths A, Beaussier AL, Demeritt D, Rothstein H, 'Intelligent Monitoring? Assessing the Ability of the Care Quality Commission's Statistical Surveillance Tool to Predict Quality and Prioritise NHS Hospital Inspections', (2017) 26 BMJ Quality and Safety 120

Griffiths D, Quick O, 'Managing Medical Manslaughter Cases: Improving Efficiency and Transparency?' Law Research Paper Series, May 2019, Paper No 007 2019, University of Bristol

Griffiths D, Sanders A (eds), Medicine, Crime and Society (Cambridge: Cambridge University Press 2013)

_ 'The Road to the Dock: Prosecution Decision-making in Medical Manslaughter Cases', in Griffiths D, Sanders A (eds), Medicine, Crime and Society (Cambridge: Cambridge University Press 2013)

Guigue J, 'Les inconvénients de la pénalisation du droit de la santé', (2008) Revue de droit sanitaire et social 36

Hall J, 'Negligence and the General Problem of Criminal Responsibility', (1972) 81 rale Law Journal 949

- General Principles of Criminal Law (Clark, NJ: The Lawbook Exchange 2010)

Hart HLA, 'Negligence, Mens Rea, and Criminal Responsibility', in Hart HLA (ed), Punishment and Responsibility: Essays in the philosophy of law (Oxford: Oxford University Press 1968)

Hennion-Jacquet P, 'Quelques aspects de l'ambivalence des responsabilités pénale et civile du praticien', (2004) 14 Revue générale de droit médicale 286

Heraud J-A, Kerr F, Burger-Helmchen T, Management créatif des systèmes complexes (London: ISTE Editions 2019) 
Hermitte MA, Le sang et le droit. Essai sur la transfusion sanguine (Paris: Seuil 1996) Herring J, Criminal Law: Text, Cases and Materials (8th edn, Oxford: Oxford University Press 2018)

Hodgson J, 'The Police, the Prosecutor and the Juge d'Instruction', (2001) 41(2) The British Journal of Criminology 344

Empirical Observations', (2002) 29(2) Journal of Law and Society 227

Horder J, Ashworth's Principles of Criminal Law (9th edn, Oxford: Oxford University Press 2019)

Husak D, 'The Criminal Law as Last Resort', (2004) 24(2) Oxford Journal of Legal Studies 217

Jamin I, 'La responsabilité pénale en milieu de soin: une préoccupation réelle, une menace relative?’ (2009) Actualité Juridique Pénal 340

Jorg N, Field S, Brants C, 'Are Inquisitorial and Adversarial Systems Converging?' in Harding C et al. (eds), Criminal Justice in Europe: A Comparative Study (Oxford: Oxford University Press 1995)

Kazarian M, The Role of the Criminal Law and the Criminal Process in Healthcare Malpractice in France and England (PhD thesis, University of Manchester 2013)

_ Tainted Blood Scandal', (2019) 27(3) Medical Law Review 390

Kazarian M, Griffiths D, Brazier M, 'Criminal Responsibility for Medical Malpractice in France', (2011) 27(4) Journal of Professional Negligence 188

King G, Keohane RO, Verba S, Designing Social Inquiry (Princeton: Princeton University Press 1994)

Kohn L, Corrigan J, Donaldson M (eds), To Err Is Human: Building a Safer Health System (Washington, DC: National Academy Press 1999)

Kyd SR, Elliott T, Walters MA, Clarkson and Keating: Criminal law (9th edn, London: Sweet and Maxwell 2017)

Lacey N, 'Responsibility Without Consciousness', (2016) 36(2) Oxford Journal of Legal Studies 219

Lacey N, Wells C, Quick O, Reconstructing Criminal Law (Cambridge: Cambridge University Press 2010)

Lacobucci G, 'CQC-style Inspections Don't Raise Standards or Improve Patient Safety, Say RCGP Members', (2018) 363 British Medical Journal 4216

Laird K, 'Filling a Lacuna: The Care Worker and Care Provider Offences in The Criminal Justice and Courts Act 2015', (2016) 37(1) Statute Law Review 1

— sion), Sir Brian Leveson PQBD, Haddon-Cave J and HH Judge Inman QC: 31 July 2017; [2017] EWCA Crim 1168', (2018) l Criminal Law Review 76

Lanham D, Bartal BF, Evans RG, 'The Purposes of Criminal Law', in Lanham D, Bartal BF, Evans RG, Wood D (eds), Criminal Laws in Australia (Alexandria: The Federation Press 2006)

Laude A, Mathieu B, Tabuteau D, Droit de la santé (3e edn, Paris: Presses Universitaires de France 2012)

Leape L, Berwick D, 'Five Years After to Err Is Human: What Have We Learned? (2005) 293(19) Journal of the American Medical Association 2384

Leape L, Berwick D et al., 'Transforming Healthcare: A Safety Imperative', (2009) 18 Quality and Safety Health Care 425 
Leveton LB, Sox Jr HC, Stoto MA, HIV and the Blood Supply (Institute of Medicine 1995)

Lijphart A, 'Comparative Politics and the Comparative Method', (1971) 65(3) American Political Science Review 682

Lindholm DD, 'Freeze-dried Factor VIII Concentrates and the NHS', (1978) 2(6150) British Medical Journal 1450

Lopez L et al., 'Disclosure of Hospital Adverse Events and Its Association with Patients' Ratings of the Quality of Care', (2009) 169(20) Quality of Care Arch intern Med 1888

Lord Woolf, 'Are the Courts Excessively Deferential to the Medical Profession?' (2001) 9 Medical Law Review 1

Machin H, 'Retooling the State Machine', in Guyomarch A, Machin H, Hall PA, Hayward J (eds), Developments in French Politics 2 (Basingstoke: Palgrave 2001)

Mannucci PM, 'AIDS, Hepatitis and Hemophilia in the 1980s: Memoirs from an Insider', (2003) 1(10) Journal of Thrombosis and Haemostasis 2065

Marchetti M, 'La genèse médiatique du "scandale du sang contaminé",' in Ethique, sida et société. Rapport d'activité du Conseil national du sida (Paris: La Documentation Française, Janvier 1993)

Mayaud Y, Violences involontaires et responsabilité pénale (Paris: Dalloz Référence 2003)

McCall Smith A, 'Clinical Negligence and the Incompetent Doctor', (1993) 1(3) Medical Law Review 336

McGivern G, Fischer M, 'Medical Regulation, Spectacular Transparency and the Blame Business', (2010) 24 Journal of Health Organisation and Management 597

Mello M, Kachalia A, Studdert D, Administrative Compensation for Medical Injuries: Lessons from Three Foreign Systems (New York, NY: The Commonwealth Fund 2011)

Memeteau G, Traité de la responsabilité médicale (Bordeaux: Les études hospitalières 1996)

Merry A, 'When Are Errors a Crime? - Lessons from New Zealand', in Erin C, Ost $S$ (eds), The Criminal Justice System and Heath Care (Oxford: Oxford University Press 2007)

Merry A, Brookbanks W, Merry and McCall Smith's Errors, Medicine and the Law (2nd edn, Cambridge: Cambridge University Press 2017)

Merry A, McCall Smith, Errors, Medicine and the Law (Cambridge: Cambridge University Press 2013)

Mistretta P, Cass.crim.7 mars 2017, No 16-80.754: omission de porter secours: le medecin urgentiste, le malade en fin de vie et les querelles de famille

Mistretta P (ed), French Law: From a Comparative Law Perspective: For an Overhaul of Medical Criminal Law? (Institut Universitaire Varenne, Colloques et Essais 2017)

Montagnier L, Des virus et des hommes (Paris: Odile-Jacob 1994)

Moore MS, Hurd HM, 'Punishing the Awkward, the Stupid, the Weak, and the Selfish: The Culpability of Negligence', (2011) 5(2) Criminal Law and Philosophy 147

Mullock A, 'Gross Negligence (Medical) Manslaughter and the Puzzling Implications of Negligent Ignorance, Rose v R [2017] EWCA Crim 1168', (2018) 26(2) Medical Law Review 350

Nicholas B, The French Law of Contract (2nd edn, Oxford: Oxford University Press 1992) 
Obadia M, 'L'expérience d'un pôle de santé publique', (2008) Revue de droit sanitaire et social 44

Oliphant K, 'Beyond Misadventure: Compensation for Medical Injuries in New Zealand', (2007) 15(3) Medical Law Review 357

— tem', (2009) 3 Opinio Juris in Comparatione 1

Ost S, Erin C, 'An Ill-Suited and Inappropriate Union? Exploring the Relationship Between the Criminal Justice System and Health Care', in Erin C, Ost S (eds), The Criminal Justice System and Health Care (Oxford: Oxford University Press 2007)

Padfield N, Bild J, Text and Materials on the Criminal Justice Process (5th edn, London: Routledge 2015)

Pakes F, Comparative Criminal Justice (4th edn, London: Routledge 2019)

Papanikolaou D, 'La responsabilité pénale des membres d'une équipe médicale', (2004) 14 Revue générale de droit medical 80

Parsons S, 'The Doctrine of Identification, Causation and Corporate Liability for Manslaughter', (2003) 67 Journal of Criminal Law 69

Poncela P, Droit de la peine (2e edn, Paris: Presses Universitaires de France 2001)

Quick O, 'Prosecuting “Gross” Medical Negligence: Manslaughter, Discretion and the Crown Prosecution Service', (2006) 33 Journal of Law and Society 421

— , 'Medical Manslaughter: The Rise (And Replacement) of a Contested Crime?' in Erin C, Ost S (eds), The Criminal Justice System and Health Care (Oxford: Oxford University Press 2007)

_ ham S, (eds), Criminal Liability for Non-Aggressive Death (Aldershot: Ashgate 2008)

— 'Medicines, Mistakes and Manslaughter: A Criminal Combination?' (2010) 69(1) Cambridge Law Journal 186

— 38 Journal of Law and Society 496

- 'Patient Safety and the Problem and Potential of Law', (2012) Journal of Professional Negligence 97

— , 'Medical Manslaughter and Expert Evidence: The Role of Context and Character', in Griffiths D, Sanders A (eds), Medicine, Crime and Society (Cambridge: Cambridge University Press 2013)

- Regulating Patient Safety: The End of Professional Dominance (Cambridge: Cambridge University Press 2017)

Quirk H, 'Sentencing White Coat Crime: The Need for Guidance in Medical Manslaughter Cases', (2013) 11 Criminal Law Review 871

Ragni MV et al., 'Acquired-Immunodeficiency-like-syndrome in Two Haemophiliacs', (1983) 321(8318) The Lancet 213

Rimbault P, 'La responsabilité pénale des décideurs et des personnes morales', XXXIVe Congrès Français de criminologie, 14 septembre 2005

Robson RA, 'Crime and Punishment: Rehabilitating Retribution as a Justification for Organizational Criminal Liability', (2010) 47(1) American Business Law Journal 124

Rolewicz L, Palmer B, 'The NHS Workforce in Numbers', The Nuffield Trust, 8 May 2019

Ruffié J, Sournia JC, La transfusion sanguine (Paris: Fayard 1996) 
Runciman W et al., 'Towards an International Classification for Patient Safety: Key Concepts and Terms', (2009) 21 International Journal for Quality in Health Care 18

Samanta A, Samanta A, 'Gross Negligence Manslaughter and Doctors: Ethical Concerns Following the Case of Dr Bawa-Garba', (2018) 45(1) Journal of Medical Ethics 10

Sanders A, 'Victims' Voices, Victims' Interests and Criminal Justice in the Healthcare Setting', in Griffiths D, Sanders A (eds), Medicine, Crime and Society (Cambridge: Cambridge University Press 2013)

— , 'The CPS-30 Years On', (2016) 2 Criminal Law Review 82

Setbon M, Pouvoirs contre sida (Paris: Seuil 1993)

Sourdille J, Huriet C, La crise du système transfusionnel français, Rapport de la commission d'enquête du Sénat (Paris: Economica 1992)

Spencer JR, 'The Victims and the Prosecutor', in Bottoms A, Roberts J (eds), Hearing the Victims: Adversarial Justice, Crime Victims and the State (Cullompton: Willan Publishing 2010)

Spencer JR, Brajeux MA, 'Criminal Liability for Negligence-a Lesson from Across the Channel?' (2010) 59 International and Comparative Law Quarterly 18

Stark F, 'Reckless Manslaughter', (2017) 10 Criminal Law Review 771

Starr D, Blood: An Epic History of Medicine and Commerce (New York, NY: Harper Collins 1998)

Sureau C, 'L'erreur, la faute, l'aléa, sanction ou prévention?' in Sureau C, Lecourt D, David G, L'erreur médicale (Sem.) (Paris: Presses Universitaires de France 2006)

Tadros V, 'Recklessness and the Duty to Take Care', in Shute S, Simester AP (Eds.), Criminal Law Theory: Doctrines of the General Part (Oxford: Oxford University Press 2002)

—, 'The Limits of Manslaughter', in Clarkson CMV, Cunningham S (eds), Criminal Liability for Non-Aggressive Death (Aldershot: Ashgate 2008)

Tapia M, 'Décadence et fin éventuelle du principe d'identité des fautes pénales et civiles' (2003) 67 Gazette du Palais 2

Taylor S, 'Providing Redress for Medical Accidents in France: Conflicting Aims, Effective Solutions?' (2011) 2(1) Journal of European Tort Law 61

- Medical Accident Liability and Redress in English and French Law (Cambridge: Cambridge University Press 2015)

Thornton P (Chief Coroner), 'The Coroner System in the 21st Century', The Howard League for Penal Reform-Parmoor Lecture 2012, October 2012

Thouvenin D, La responsabilité médicale, Analyse des données statistiques disponibles et des arrêts rendus par la cour de cassation et le conseil d'état de 1984 à 1992 (Paris: Médecine-Sciences Flammarion 1999)

Tombs S, 'The UK's Corporate Killing Law: Un/fit for Purpose?' (2018) 18(4) Criminology and Criminal Justice 488

Tombs S, Whyte D, The Corporate Criminal, Why Corporations Should Be Abolished (London: Routledge 2015)

Trubek LG et al., 'Health Care and New Governance: The Quest for Effective Regulation', (2008) 2 Regulation and Governance 1

Turcey V, 'Le point de vue du magistrat', in Dreyfuss D, Lemaire F, Outin H (eds), La judiciarisation de la médecine (Paris: Médecine-Sciences Flammarion 2004)

Ulfbeck V, Hartley M, Schultz M, 'Malpractice in Scandinavia', (2012) 87(1) Chicago-Kent Law Review 111 
Van Den Wyngaert C, Criminal Procedure Systems in the European Community (London: Butterworths1993)

Van Ruymbeke R, Le juge d'instruction (Paris: Presses Universitaires de France 2016)

Vaughan J, Quick O, Griffiths D, 'Medical Manslaughter: Where Next?' (2018) 100(6) The Royal College of Surgeon bulletin 251

Verrest P, 'The French Public Prosecution Service', (2000) 8(3) European Journal of Crime, Criminal Law and Criminal Justice 210

Vidmar N, Lempert R, Seidman Diamond S, Hans V, Landman S et al., 'Amicus Brief: Kumbo Tire v Carmichael, (2000) 24 Law and Human Behaviour 387

Vignaud F, 'La judiciarisation de la médecine, comparaison entre droit français et droit américain', in Dreyfuss D, Lemaire F, Outin H (eds), La judiciarisation de la médecine (Paris: Médecine-Sciences Flammarion 2004)

Walshe K, Regulating Healthcare: A Prescription for Improvement (Maidenhead: Open University Press 2003)

Waterson AP, 'Acquired Immune Deficiency Syndrome', (1983) 286 British Medical Journal 743

Watson A, Legal Transplants. An Approach to Comparative Law (2nd edn, Athens, GA: The University of Georgia Press 1993)

Wells C, 'Medical Manslaughter: Organisational Liability', in Griffiths D, Sanders A (eds), Medicine, Crime and Society (Cambridge: Cambridge University Press 2013)

Wester-Ouisse V, 'Dépénalisation du droit médical', (2008) Hors Série juillet Revue générale de droit medical 245

Williams G, Criminal Law: The General Part (2nd edn, London: Stevens and Sons Ltd 1964)

Yeung K, Horder J, 'How Can the Criminal Law Support the Provision of Quality in Healthcare?' (2014) 23 BMJ Quality and Safety 519

Yin RK, 'The Case Study Crisis: Some Answers', (1981) 26(1) Administrative Science Quarterly 58

- Case Study Research: Design and Methods (5th edn, Thousand Oaks, CA: Sage 2014)

Zweigert Z, Kotz H, An Introduction to Comparative Law (3rd edn, Oxford: Oxford University Press 1998)

Gosport War Memorial Hospital: The report of the Gosport Independent Panel, 20 June 2018

Haemophilia Society React to Government Response to the Archer Report, date unknown Infected Blood Inquiry, Terms of Reference, July 2018

Infected Blood Inquiry, First Witness Statement of Graham Manning, WITN1367001, 7 June 2019

Infected Blood Inquiry, Written Statement of Annette Hill-Stewart, WITN1001001, 12 July 2019

Infected Blood Inquiry, Written Statement of Barry Fitzgerald, WITN2819001, 12 August 2019

Infected Blood Inquiry, Written Statement of Gaynor Lewis, WITN2368001, 15 February 2019

Infected Blood Inquiry, Written Statement of Louise Marsden, WITN1371001, April 2019

Infected Blood Inquiry, Written Statement of Maria Fletcher, WITN1876001, 14 February 2019 
Infected Blood Inquiry, Written Statement of Mr L, WITN0148001, 16 October 2018

Infected Blood Inquiry, Written Statement of Susan Threakall, WITN1564001, December 2018

Assemblée Nationale, Rapport de la commission d'enquête sur l'état des connaissances scientifiques et les actions menées à l'égard de la transmission du sida (Union générale d'édition 1993)

Assemblée Nationale, Rapport $n^{\circ} 2266$ fait au nom de la commission des lois constitutionnelles, de la législation et de l'administration générale de la République sur la proposition de loi, adoptée par le Sénat, tendant à préciser la définition des délits non intentionnels, par M René Dosière, 22 mars 2000

Berwick D, Improving the Safety of Patients in England, a Promise to Learn-A Commitment to Act, National Advisory Group on the Safety of Patients in England, August 2013

British Medical Association, Doctors' Titles: Explained, 2017

Care Quality Commission, Annual Report and Accounts 2018/19, July 2019

Care Quality Commission, Registration Under the Health and Social Care Act 2008, Warning Notices, Guidance for Registered Providers and Managers, October 2015

Commission Justice pénale et Droits de l'homme, La mise en état des affaires pénales, Rapport final, Paris: La Documentation française 1991E

Department of Health, An Organisation with a Memory: Report of an Expert Group on Learning from Adverse Events in the NHS Chaired by the Chief Medical Officer, London: HMSO 2000

Department of Health, Self-Sufficiency in Blood Products in England and Wales, a Chronology from 1973 to 1991, 2006

Department of Health, Written Ministerial Statement, Support to Those Affected by Contaminated Blood, 14 October 2010

Department of Health, Criminal Offence of Ill-treatment or Wilful Neglect, Impact Assessment, June 2014

Department of Health, New Offence of Ill-treatment or Wilful Neglect, Government Response to Consultation, June 2014

Department of Health, Gross Negligence Manslaughter in Healthcare, The Report of a Rapid Policy Review, June 2018

Eleanor Grey QC, Professor Sir Ian Kennedy, The Report of the Independent Review of Children's Cardiac Services in Bristol, June 2016

Francis R, Independent Inquiry into Care Provided by Mid Staffordshire NHS Foundation Trust January 2005-March 2009, Vol I and II (2010)

General Medical Council, Fair to refer? Reducing disproportionality in fitness to practise concerns reported to the GMC, June 2019

General Medical Council, HIV Infection and Aids: The Ethical Considerations, 1988, PEN0161165

General Medical Council, Independent Review of Gross Negligence Manslaughter and Culpable Homicide, June 2019

Health and Safety Executive, Work-related Deaths, a Protocol for Liaison (England and Wales), February 2016

Health and Safety Executive, Health and Safety at Work, Summary Statistics for Great Britain 2019, October 2019

House of Commons Debates, Contaminated Blood and Blood Products, HC Deb, 14 October 2010, vol 516, cols 521-571 
James G (Chair), Report of the Independent Inquiry into the Issues Raised by Paterson, February 2020

Lucas M, Transfusion Sanguine et SIDA en 1985, Chronologie des faits et des décisions pour ce qui concerne les hémophiles, Inspection Générale des Affaires Sociales, Septembre 1991 Annexe 5: Ministère des affaires sociales et de la solidarité nationale, Secrétariat d'Etat chargé de la santé, Direction générale de la santé, Circulaire relative à la prévention de l'éventuelle transmission du syndrôme d'immunodépression acquise (SIDA) par la transfusion sanguine, DGS $/ 3 \mathrm{~B} \mathrm{n}^{\circ}$ 569, 20 juin 1983

MACSF, Rapport Annuel 2016 Sur La Sinistralité, Synthèse Des Chiffres Clés

MACSF, Rapport Annuel 2018 Sur La Sinistralité, Synthèse Des Chiffres Clés

MPTS, GMC, Sanctions guidance for members of medical practitioners tribunals and for the General Medical Council's decision makers, April 2017

Mr Justice Horace Krever, Commission of Inquiry on the Blood System in Canada, Final Report Vol. 3, 1997

Oxford Haemophilia Centre, Trials of 'Hepatitis Reduced' Factor VIII-an Update, 29 March 1984

Professional Standards Authority for Health and Social Care, Right-touch Regulation, October 2015

Research and Development Department, BPL, Annual Report to December 1984

Rt Hon Lord Archer et al., Independent Public Inquiry Report on NHS-Supplied Contaminated Blood and Blood Products, February 2009

Rt Hon Lord Penrose, The Penrose Inquiry Final Report, March 2015

Sénat, Session ordinaire de 1995-1996, Annexe au procès-verbal de la séance du 18 octobre $1995, \mathrm{~N}^{\circ} 32$, Proposition de loi relative à la responsabilité pénale des élus locaux pour des faits d'imprudence ou de négligence commis dans l'exercice des fonctions, Rapport

Sénat, Les délits non intentionnels-La Loi Fauchon: 5 ans après, Actes du colloque, ler mars 2006, Palais du Luxembourg

Supraregional Haemophilia Reference Centre, Royal Free Hospital, London, Blood Products and their Problems, March 1984

Toft B, External Inquiry into the Adverse Incident That Occurred at Queen's Medical Centre, Nottingham, Department of Health, 4 January 2001

The All-Party Parliamentary Group on Haemophilia and Contaminated Blood, Inquiry into the Current Support for Those Affected by the Contaminated Blood Scandal in the UK, January 2015

The Law Commission, Legislating the Criminal Code: Involuntary Manslaughter (Law Com No 237) Item 11 of the Sixth Programme of Law Reform: Criminal Law, 4 March 1996

The Sentencing Council, Health and Safety Offences, Corporate Manslaughter and Food Safety and Hygiene Offences, Definitive Guideline, 2015

UK Government, Government Response to Lord Archer's Independent Inquiry Report on NHS-supplied Contaminated Blood and Blood Products, 20 May 2009

'Affaire de l'hormone de croissance: relaxe des deux derniers prévenus en vie', Le Monde (25 January 2016)

'Anger as Fatal Jab Doctor Freed', BBC News (23 September 2003)

'Blood Scandal That Cannot Go Unpunished', Mail on Sunday (9 July 1995)

'Breast Implants: PIP's Jean-Claude Mas Gets Jail Sentence', BBC News (10 December 2013) 
'Contaminated Blood: Victims Can Launch Court Damages Action', BBC News (26 September 2017)

'David Sellu Trial: Doctor's Conviction Over Patient's Death Quashed', BBC News (15 November 2016)

'Doctor and Nurse Given Suspended Jail Terms Over Boy's Negligence Death', The Guardian (14 December 2015)

'Haemophiliac HIV Tragedy "Needless"', BBC News (3 August 2001)

'Hépatite B: Deux grands laboratoires mis en examen pour "tromperie aggravée"', Libération (1 February 2008)

'Hospital Trust Fined for Knee op Death', The Guardian (11 April 2006)

'Ian Paterson: "Sheer Volume" of Victims Delays Breast Surgeon Report', BBC News (5 April 2019)

“"Liver Branding” Surgeon Simon Bramhall Fined $£ 100,000$ ', BBC News (12 January 2018)

'PIP: Les Trois Clés d'une Enquête Complexe', Le Figaro (27 January 2012)

“ "No One to Be Prosecuted” Over Mid-Staffs Scandal', The Telegraph (1 March 2016)

'Scandale de l'amiante: 705 nouveaux dossiers de victimes', Le Point (4 April 2012)

'Shipman Jailed for 15 Murders', BBC News (31 January 2000)

'Struck Off Dr Hadiza Bawa-Garba Wins Appeal to Work Again', BBC News (13 August 2018)

'Tetraplegic Man's Life-support Turned Off by Mistake', BBC News(25 October 2010)

Alleyne R, 'Surgeons Who Removed the Wrong Kidney Are Cleared', The Telegraph (26 June 2002)

Black D, 'Police Drop 'Bad Blood' Scandal', The Journal (7 July 2003)

Boseley S, 'Doctors Sign Letter Expressing Worry Over Criminalisation of Surgeon', The Guardian (6 August 2015)

— , 'Gosport Hospital: More Than 450 Patients Died Due to Opioid Drugs Policy', The Guardian (20 June 2018)

Boseley S, Topping A, “"A Horrific Human Tragedy”: Report Criticises Response to Blood Scandal', The Guardian (24 February 2009)

Bowcott O, 'Ministers Reject Calls for Immediate Compensation for Infected Blood Victims', The Guardian (28 January 2020)

Carvel J, 'The Day in Politics: Old Lobbying Virtues Win Victory for AIDS Case', The Guardian (17 November 1987)

Cazi E, 'Le scandale du Mediator en procès', Le Monde (21 September 2019)

Favereau E, 'Le procès du sang contaminé. Les trois accusés et l'avenir. Georgina Dufoix non coupable. Son action a été jugée positive', Libération (10 March 1999)

— , 'Laboratoires Servier: anatomie d'un système', Libération (20 September 2019)

Gaetner G, 'Le procès d'un scandale', L'express (6 February 2008)

—, 'Les juges d'instruction sont les mal aimés du système pénal français', L'Express (8 January 2009)

Gorman S, 'Those Left Behind by the Contaminated Blood Scandal Shouldn't Have to Fight for Support', The Guardian (16 April 2019)

Jouan A, Lombard MA, 'La Chronologie de l'Affaire', Le Nouvel Observateur (15 January 2009)

Katz G, 'No Individual Blame in UK's Tainted Blood Scandal', ABC News International (23 February 2009)

Keller A, 'We Just Wanted the Law to Recognise Our Mum Had Been Killed', Lichfield Mercury (12 February 2009) 
Metthews-King A, 'Bawa-Garba Latest: Jeremy Hunt Orders Review into Manslaughter by Gross Negligence Rulings in the NHS', The Independent (6 February 2018)

Sawer P, Donnelly L, 'Stafford Hospital Trust Admits 'Significant' Health and Safety Breaches Related do Deaths of Four Patients', The Telegraph (4 November 2015)

Smyth C, 'New NHS Scandal Is Inevitable, Mid Staffs Inquiry Chief Warns', The Times (10 February 2017)

Topping A, 'Breast Surgeon Ian Paterson Jailed for 15 Years for Carrying Out Needless Operations', The Guardian (31 May 2017)

Walker P, Topping A, 'Theresa May Orders Contaminated Blood Scandal Inquiry', The Guardian (11 July 2017)

$A$ and other $v$ National Blood Authority and Another [2001] 3 All ER 289

$A B v$ Leeds Teaching Hospital Trust [2014] EWHC 644

Bawa-Garba v GMC [2018] EWCA Civ 1879

DPP v Kent and Sussex Contractors [1944] KB 146, DC

HIV Haemophiliac Litigation [1990] 41 BMLR 171

Lennards Carrying Co. Ltd v Asiatic Petroleum Ltd [1915] AC 705, HL

Montgomery $p$ Lanarkshire Health Board [2015] UKSC 11

Pearce v United Bristol Healthcare NHS Trust [1999] PIQR 53

$R v$ Adomako [1994] 3 WLR 288

$R v$ Bawa-Garba [2016] EWCA Crim 1841

$R v$ Caldwell [1982] AC 341 (HL)

$R v$ Cato (1976) 62 Cr App R 41

$R v$ Cunningham [1957] 2 QB 396

$R v$ Dica [2004] 3 All ER 593

$R v$ Errol Cornish and Maidstone and Tunbridge Wells NHS Trust [2015] EWHC $2967(\mathrm{QB})$

$R v$ Garg (Sudhanshu) [2012] EWCA Crim 2520

$R v$ Honey Maria Rose [2017] EWCA Crim 1168

$R$ v ICR Haulage Ltd [1944] KB 551, CCA

$R v$ Kennedy (No 2) [2008] UKHL 1 AC 269

$R v$ Mellor [1996] 2 Cr App R 245

$R v$ Mid Staffordshire NHS Foundation Trust, Sentencing Remarks of the Hon Mr Justice Haddon-Cave, 28 April 2014

$R v$ Misra; $R$ v Srivastava [2004] EWCA Crim 2375

$R v$ Mowatt [1968] 1 QB 421

$R v$ Prentice and another; $R v$ Adomako; $R v$ Holloway [1993] 4 All ER 935

$R v$ Rudling [2016] 151 BMLR 79

$R v$ Savage, $R v$ Parmenter [1992] 1 AC 699 (HL)

$R v$ Southampton University Hospital NHS Trust [2006] EWCA Crim 2971

$R v$ Wilson, $R v$ Jenkins [1984] AC 242

Sidaway $v$ Board of Governors of the Bethlem Royal and the Maudsley Hospital [1985] 1 All ER 643

Tesco Supermarket Ltd v Nattrass [1972] AC 153

CA Grenoble, 12/06/1998, affaire du Drac

CA Nancy 29/03/2001

Cass Crim 22/06/1994 in Pradel J (Dir) Sang et droit pénal: A propos du sang contaminé, Travaux de l'Institut de Sciences Criminelles, vol XIV (Editions Cujas 1994) 
Cass Crim 18/06/2002 Bull Crim no 138

Cass Crim 24/09/2003 no 02-81.820

Cass Crim 17/12/2003 no 00-87.872

Cass Crim 10/01/2006 no 04-86.428

Cass Crim 13/02/2007 no 06-82.202 Bull Crim 2007 no 44, 261

Cass Crim 10/02/2009 no 08-80.679 Bull Crim 2009, no 33

Cass Crim 13/04/2010 no 09-86.429

Cass Crim 11/09/2012 no 11-88.269

Cass Crim 16/10/2013 no 12-81.532

Cass Crim 19/04/2017 no 16-83640

Cass Crim 11/07/2017 n 16-86.092

Cass Crim 15/01/2019 no 17-86461

Commission d'instruction de la Cour de Justice de la République, Arrêt portant renvoi devant la Cour de Justice de la République, 17 juillet 1998, D6137

Cour de justice de la République, arrêt 9/03/1999, affaire no 99-001

Réquisitions de Joseph Perfetti, Avocat général près la chambre criminelle de la cour de cassation in Pradel J (Dir.), Sang et droit pénal: A propos du sang contaminé, Travaux de l'Institut de Sciences Criminelles, vol XIV (Editions Cujas 1994)

TGI de Paris, $16^{\text {e }}$ Chambre, jugement du 3/09/2003 affaire n 9926423046

TGI de Paris, Ordonnance de transmission du dossier et des pièces à conviction au procureur général et de non lieu partiel, D20917

Children and Young Persons Act 1933

Company Directors Disqualification Act 1986

Consumer Protection Act 1987

Coroners and Justice Act 2009

Corporate Manslaughter and Corporate Homicide Act 2007

Criminal Justice and Courts Act 2015

Criminal Justice and Courts Act 2015 Explanatory Notes

Director of Public Prosecution, Code for Crown Prosecutors, 26 October 2018

Health Act 1999

Health and Safety at Work Act 1974

Health and Social Care Act 2008

Health and Social Care Act 2008 (Regulated Activities) Regulations 2014

Legal Aid, Sentencing and Punishment of Offenders Act 2012

Mental Capacity Act 2005

Mental Health Act 1983

NHS Reform and Health Care Professions Act 2002

Offences Against the Person Act 1861

Police and Criminal Evidence Act 1984

Circulaire DGS/PS3/DH/PHI No 9631 du 19 janvier 1996 relative au rôle et aux missions des aides-soignants et des auxiliaires de puériculture dans les établissements hospitaliers

Code Civil

Code Pénal

Code de la consommation

Code de la santé publique

Code de procédure pénale

Décret $\mathrm{n}^{\circ}$ 93-345 du 15 mars 1993 relatif aux actes professionnels et à l'exercice de la profession d'infirmier, JORF no 63 du 15 mars 1993, 4098 
Loi du ler août 1905 sur les fraudes et falsifications en matière de produits ou de services

Loi $\mathrm{n}^{\circ}$ 2000-516 du 15 juin 2000 renforçant la protection de la présomption d'innocence et les droits des victims

Loi n ${ }^{\circ}$ 2002-303 du 4 mars 2002 relative aux droits des malades et à la qualité du système de santé

Loi no 2018-703 du 3 août 2018 renforçant la lutte contre les violences sexuelles et sexistes

Injury, Prevention, Rehabilitation and Compensation Act 2001 (New Zealand)

Interview with A (Cambridge, UK, 3 February 2011)

Interview with B (Paris, France, 17 January 2011) 